

\section{VOL. XXI.-1906.}

\section{THE}

\section{JOURNAL OF LARYNGOLOGY}

\section{RHINOLOGY, AND OTOLOGY;}

AN ANALYTICAL RECORD OF CURRENT LITERATURE

RELATING TO

\section{THE THR0AT, NOSE, AND EAR.}

PUBLISHED MONTHLY.

\section{af $\mathfrak{n} \mathfrak{n} \mathfrak{t} \mathfrak{n} \mathfrak{n}$ :}

ADLARD AND SON, BARTHOLOMEW CLOSE. 


\section{THE JOURNAL OF LARYNGOLOGY, RHINOLOGY, AND OTOLOGY.}

Founded in 1887 by MORELL MACKENZIE and NORRIS WOLFENDEN.

EDIToRs :

JOHN MACINTYRE, M.B., M.Ch., F.R.S.E. DUNDAS GRANT, M.A., M.D., F.R.C.S.Eng. ARTHUR SANDFORD, M.D., M.Ch.R.U.I. W. MILLIGAN, M.D., M.Ch.

Managing Sub-Editor :

W. JOBSON HORNE, M.A., M.D., B.C.Cantab., M.R.C.P.Lond.

WIYH THE CO-OPERATION OF

Drs. Price-Brown (Toronto), Cartaz (Paris), Bryson Delavan (New York),

Dodd (Chicago), Donelan (London), Clayton Fox (London), Gray (Glasgow), Grazzi (Florence), Hicguet (Brussels),

Middemass Hunt (Liverpool), Hutchison (Brighton), Joal (Paris), Kelly (Glasgow),

Lacoarret (Toulouse), Lichtwitz (Bordeaux), Lreven (Aix-la-Chapelle),

John N. Mackenzie (Baltimore), Prof. Massei (Naples), McCalu (Bournemouth),

Meyjes (Amsterdam), Mrles (New York), Holger Mraind (Copenhagen),

Chichele Nourse (London), Porter (St. Louis), Know les Renshaw (Manchester),

Sachs (Hamburg), Sajous (Philadelphia), Sendziak (Warsaw), Sota (Seville),

StClatr Thomson (London), Hunter Tod (London), Woods (Dublin),

Macleod Yearsley (London), and Ziem (Dantzic). 


\section{LIST OF PLATES.}

Plate. To Illustrate Mr. Cuthbert Morton's Paper on Some New Instruments for Removing Foreign Bodies FROM THE BRONCHI BY DIRECT BRONChOSCOPY

Plate. To Illugstrate Mr. Hugh E. Jones's Case of Angeioma of THE AURICle

Portrait of the late W. R. H. Stewart, F.R.C.S.Ed. . 213

Piate. To Illustrate Dr. Price-Brown's Paper on a New Operation for Extreme Cases of Septal Deflection, with Presentation of a Successful Result in an Adult Case

Portrait of the late W. Spencer Watson, M.B.Lond., F.R.C.S.

\section{ILLUSTRATIONS IN TEX'T.}

An Aseptic Syringe

Temperature Chart to Illugstrate Dr. Dundas Grant's Case of Jugular Bulb Pyamia and Cerebelitar Abscess

Chart to Illustrate Sir A. E. Wright's Remarks explanatory of the Treatment of Dr. Scanes Spicer's Case of Inoperable Cancer of the FaUCES

Figs. 1-9.-To Illustrate Dr. Dundas Grant's Address on Some Practical Problems in Otology and Rhinology

Figs. 1-6.-Duration Charts . . . 408-412

Fig. 7.-The Inspiratory Nasal Douche . . 418

Fig. 8.-Sondermann's Nasal Suction Apparatus . . 419

Fig. 9.-Leduc's Laryngeal Powder Inhaler . . 420 
The Index (pp. $\mathbf{i}$-liii) to Volume $X X$ is now ready, and copies have been forwarded to Subscribers. The price to non-subscribers is $2 /-$.

\section{CONTENTS.}

\section{Special Articles-}

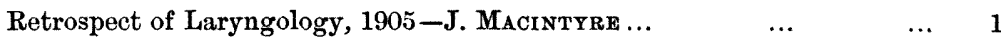

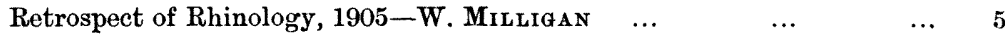

Retrospect of Otology, 1905-Dundas Grant and Chichele Nourse $\quad \ldots \quad 7$

Some New Instruments for Removing Foreign Bodies from the Bronchi by Direct Bronchoscopy (with plate)-W. CutrBert Morton $\quad \ldots \quad 12$

\section{Societies' Proceedings-}

British Laryngological, Rhinological, and Otological Association. Election of Officers. Communications by Wratt Wingrave, Chichele Nourse, A. Wrate, Stuart-Low. Presidential Address by R. H. Woons ...

… $\quad \ldots \quad \ldots$

Laryngological Socinty of London. Communications by Sir Felix Skmon, J. Donelan, Jobson Horne, Scanes Sprcer, Watson Williams, H. Barwell, P. de Santi, Brown Kelly, Petrers, Dundas Grant, G. C. Cathcart, W. Hill $\quad$.. $\quad \ldots \quad$..

Otological Society of the United Kingdom. Valedictory Address by President. Thomas Barr $\quad \ldots \quad \ldots \quad \ldots \quad \ldots$

The Prevention of Ear Affections due to Exposure to Loud Noises and to Explosives-A. H. Cheatle, Herbert Tilley, Cresswell Baber, W. Milligan, H. Mole, Edward law, M. Yearsley, Urban Pritchard, Dundas Grant, C. H. Fagge, A. E. Cumberbatch, Thomas Barr, G. Jackson

\section{Notes-}

Annual Meeting of Otological Society of United Kingdom. Election of Officers

$$
\cdots
$$

$$
\cdots
$$$$
\cdots
$$

Abstracts-

FAuces.-Carcinoma of the Tongue.-The Lymphoid Tonsillar Circle ...

Nose.-Inflammation of the Nasal Mucous Membrane.-Two Cases of

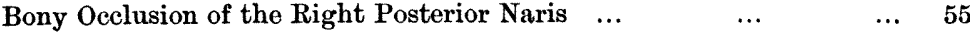

Thrrom.-The Medical Treatment of Exophthalmic Goitre... $\quad \ldots \quad 55$

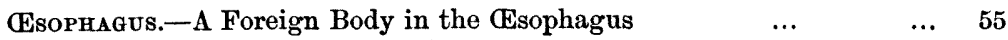

EAR.-The Pathological Conditions found in the Case of an Individual

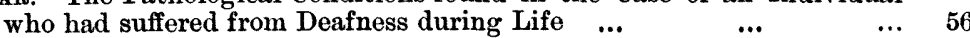

\section{Therapeutic Preparations-}

Formawn

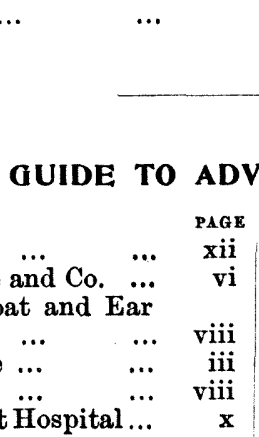

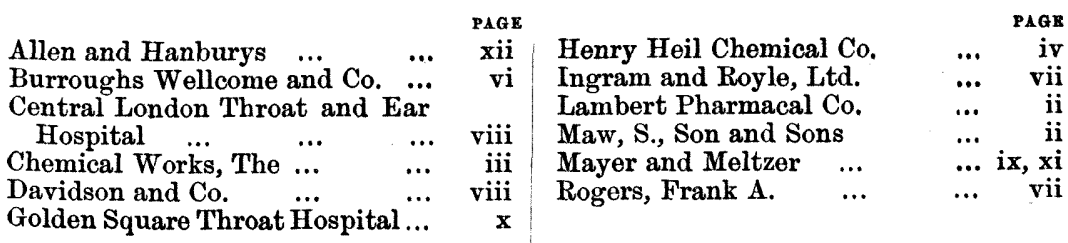




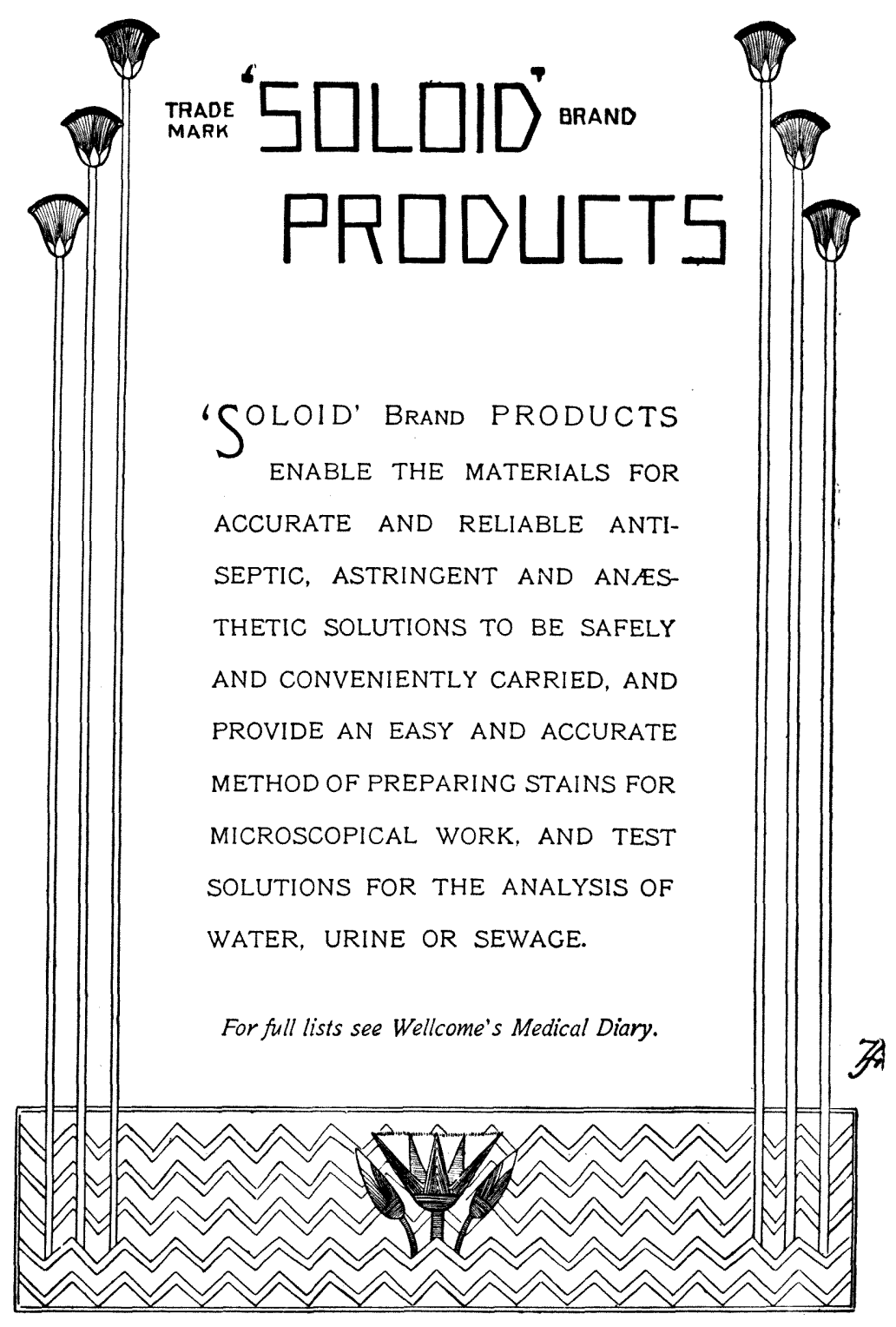

Burroughs Wellcome \& Co., london and sydney. [COPYRIGHT]

F 173 